\title{
原著
}

\section{非フッ素地区学童にみられる斑状崡一Idiopathic mottling（いわゆる非フッ素性斑状歯）一および}

尿中フッ素濃度について（Fluoride study No. 12)

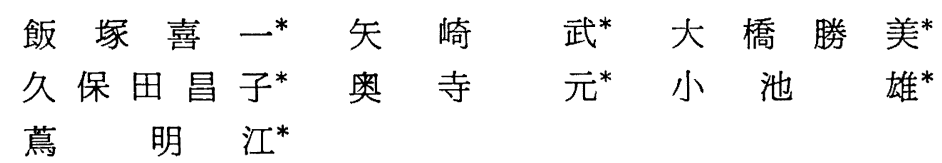

\begin{abstract}
掫要 : 飲料水低フッ素 $(\mathrm{F})$ 地域に 4 年以上に亘つて生活する，6 11歳の学童 1678 名について，斑状 歯調査ならびに尿中 F 整度の測定を行なつた。その結果, 一歯列に存在する最高度の 2 歯といら WHO 基準促従うと，おおよそ11.1\%が $\mathrm{M}_{1}$ 程度の斑状歯を有することになる。また一歯列に左右対称，4歯 以上存在するものの最高度の 2 歯といら著者らの基準に従えば, 約 $4.5 \%$ が $\mathrm{M}_{1}$ と判定された。とにか く $\mathrm{M}_{1}$ 以上と考えられる歯を 1 歯でも有する者は $25.6 \%$ に達する。

朝起床後の尿について, 尿中 $\mathrm{F}$ 䟴度の測定その他の検查を行なつたところ, 尿中 $\mathrm{F}$ 濃度は低学年から

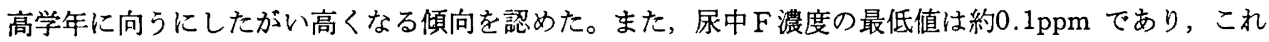
は比較的安定していた。したがつて，Fによる污染の判定には，この最低値の変動（いわば右方移動） を評価の基準とすることが良いのではないかと考えられた。さらに，尿蛋白が陽性を示す者と F濃度の 高い者の間には有意な正の相関を認め，興味がもたれた。
\end{abstract}

\section{はじめに}

現在，斑状歯とは，飲料水中に過剩に含まれる フッ素によつて惹起されたエナメル質の形成不全 歯であり， hypocalcification による白濁や hypoplasia を呈し，二次的に着色を認めるものもあ る，と定義ゔけられている。しかし，フッ素によ るものとは思われないいわゆる “斑状歯”も結構 見られるものである。したがつて，斑状歯はフッ 素によつて起きたものと，そうではないものとに 分けて考えられる心゙きものであり，実際にフッ素 性なのかあるいは非フッ素性なのかを考慮しなげ ればならないような場合が多くある。しかし現状
は，この非フッ素性斑状歯（いわゆる Idiopathic mottling など）の出現とその病因に関する資料不 足から，ただ感覚的に判断する場合が多く，公衆 歯科衛生学においても一つの問題点として残され てきた。これらの考えに基うきき, 今回, 飲料水高 フッ素地帯でもなく，また人工的フッ素污染もな いと考えられる地域の小学校児童について，とく に斑状歯および尿中フッ素濃度に関する調査を行 ない，一応の結果を得ることができたので報告す る。

\section{方法}

神奈川県藤沢市の小学校 A, B 2 校を対象とし,

* 神奈川歯科大学, 口腔衛生学教室（主任: 飯塚意一教授)

* Department of Dental Health and Preventive Dentistry, Kanagawa Dental College, Yokosuka, Japan. (Chief: Prof. Y. Iizuka)

昭和 49 年 7 月 1 日受付 
斑状歯についての口腔診查を行なつた。斑状歯の 程度の診断はその基準に問題があるが"1)，一応厚 生省基準 ${ }^{2}$ に従つた。診查児童数は $\mathrm{A}$ 校 1156 名， B校1044名，合計2200名（男子1157名，女子 1043 名）であるが，このうち生後から 8 歳までの間， 4 年以上に亘つて同市で生活していたもののみ, 1678名（男子891名，女子787名）を調査対象とし た。

藤沢市の 飲料水（市営上水道）中フッ素濃度は tap water としての最高が $0.24 \mathrm{ppm}$ で，大体 0.1 〜 $0.2 \mathrm{ppm}$ の範囲であり，約 $90 \%$ の児童はこれ を飲用している。その他(約10\%) が飲用している 井戸水のフッ素濃度も $0.15 \mathrm{ppm}$ 以下である。ま た，この市には，他に斑状歯発生の原因になりう るような環境状況は，対象児童の永久歯形成期に おいても，とくにないものと考えられる。

A 校の全児童については，同時に，朝起床後は じめの尿をとり，尿中フッ素濃度を測定し，また 尿蛋白，尿糖，尿 $\mathrm{pH}$ についても検査した。フッ
素濃度はフッ素イオン電極 (オリオン社)により， 蛋白，糖，jH は試験紙 (Combistix・Ames 社) によつて行なつた。

\section{成 綨}

個人の斑状歯の程度の判定を，一歯列に左右対 称に，数歯（ふつう4 歯）以上存在するものの最 高度の 2 歯を以つてする方法 (著者らの方法) ${ }^{1}$, および，単に一歯列に存在する 斑状歯の最高度の 2 歯を以つて判定する方法 (WHO の方法) ${ }^{3)}$ とに 分けて行なった。表 1 は著者らの方法で判定した 場合, 表 2 はHO の方法で判定した場合の成 績である。

著者らの方法に従つて判定すると，表 1 のよう に, $\mathrm{M}_{0}$ と判定されるものは平均 $8.2 \%, \mathrm{M}_{1}$ と判 定されるもの平均 $4.5 \%$ ，このうちいわゆる明ら かな白斑状としてみられる enamel opacities (white flecks) は平均 $2.0 \%$ であつた。

WHO の方法に従うと（表 2 ), 当然いわゆる斑

表 1 斑状歯の判定（著者らの方法*)

\begin{tabular}{|c|c|c|c|c|c|c|c|c|}
\hline \multirow{2}{*}{ 学年 } & \multirow{2}{*}{ 性 } & \multirow{2}{*}{ 人 数 } & \multicolumn{2}{|c|}{$\mathrm{M}_{0}$} & \multicolumn{2}{|c|}{$\mathrm{M}_{1}$} & \multicolumn{2}{|c|}{$\mathrm{M}_{2}$} \\
\hline & & & 実数 & $\%$ & 実数 & $\%$ & 実数 & $\%$ \\
\hline \multirow{2}{*}{1} & $\hat{\jmath}$ & 196 & 10 & 5.1 & $3(1) * *$ & $1.5(0.5)$ & - & - \\
\hline & 오 & 161 & 8 & 4.9 & $5(3)$ & $3.1(1.9)$ & - & - \\
\hline \multirow{2}{*}{2} & $\hat{\delta}$ & 171 & 9 & 5.2 & $6(2)$ & $3.5(1.2)$ & - & - \\
\hline & 우 & 138 & 3 & 2.1 & $1(0)$ & $0.7(0)$ & - & - \\
\hline \multirow{2}{*}{3} & 今 & 159 & 10 & 6.2 & $7(2)$ & $4.4(1.2)$ & - & - \\
\hline & 우 & 152 & 8 & 5.2 & $6(1)$ & $3.9(0.6)$ & - & - \\
\hline \multirow{2}{*}{4} & 今 & 144 & 17 & 11.8 & $9(5)$ & $6.3(3.5)$ & - & - \\
\hline & 우 & 117 & 10 & 8.5 & $6(4)$ & $5.1(3.4)$ & - & - \\
\hline \multirow{2}{*}{5} & $\hat{\sigma}$ & 108 & 13 & 12.0 & $10(4)$ & $9.2(3.7)$ & 一 & - \\
\hline & 우 & 112 & 15 & 13.3 & $4(1)$ & $3.5(0.9)$ & - & - \\
\hline \multirow{2}{*}{6} & $\hat{0}$ & 113 & 17 & 15.0 & $11(4)$ & $9.7(3.5)$ & - & - \\
\hline & 우 & 107 & 19 & 17.7 & $8(7)$ & $7.4(6.5)$ & - & - \\
\hline \multirow{2}{*}{ 計 } & 今 & 891 & 76 & 8.5 & $46(18)$ & $5.2(2.0)$ & - & - \\
\hline & 우 & 787 & 63 & 8.0 & $30(16)$ & $3.8(2.0)$ & - & - \\
\hline Total & - & 1,678 & 139 & 8.2 & $76(34)$ & $4.5(2.0)$ & - & - \\
\hline
\end{tabular}

* 一歯列にほぼ左右対称に数歯以上（4歯以上）存在するものの最高度の 2 歯で判定。

**（）内はいわゆる enamel opaque. 
表 2 斑状歯の判定 (WHO の方法*)

\begin{tabular}{|c|c|c|c|c|c|c|c|c|}
\hline \multirow{2}{*}{ 学年 } & \multirow{2}{*}{ 性 } & \multirow{2}{*}{ 人 数 } & \multicolumn{2}{|c|}{$\mathrm{M}_{0}$} & \multicolumn{2}{|r|}{$\mathrm{M}_{1}$} & \multicolumn{2}{|c|}{$\mathrm{M}_{2}$} \\
\hline & & & 実数 & $\%$ & 実数 & $\stackrel{\circ}{\circ}$ & 実数 & $\%$ \\
\hline \multirow{2}{*}{1} & $\hat{o}$ & 196 & 15 & 7.7 & $7(1)^{* *}$ & $3.6(0.5)$ & - & - \\
\hline & 우 & 161 & 25 & 15.5 & $7(4)$ & $4.3(2.5)$ & - & - \\
\hline \multirow{2}{*}{2} & $\$$ & 171 & 26 & 15.2 & $11(6)$ & $6.4(3.5)$ & - & - \\
\hline & 우 & 138 & 21 & 15.2 & $7(3)$ & $5.1(2.2)$ & - & - \\
\hline \multirow{2}{*}{3} & 今 & 159 & 36 & 22.6 & $20(8)$ & $12.6(5.0)$ & - & - \\
\hline & 우 & 152 & 40 & 26.3 & $20(6)$ & $13.2(3.9)$ & - & - \\
\hline \multirow{2}{*}{4} & 占 & 144 & 32 & 22.2 & $34(14)$ & $23.6(9.7)$ & $1(1)$ & $0.7(0.7)$ \\
\hline & 우 & 117 & 42 & 35.9 & $16(11)$ & $13.7(9.4)$ & - & - \\
\hline \multirow{2}{*}{5} & 今 & 108 & 24 & 22.2 & $15(8)$ & $13.9(7.4)$ & - & - \\
\hline & 우 & 112 & 31 & 27.7 & $8(1)$ & $7.1(0.9)$ & - & 一 \\
\hline \multirow{2}{*}{6} & 字 & 113 & 29 & 25.7 & $22(6)$ & $19.5(5.3)$ & - & - \\
\hline & 우 & 107 & 38 & 35.5 & $20(14)$ & $18.7(13.1)$ & - & - \\
\hline \multirow{2}{*}{ 計 } & $\hat{o}$ & 891 & 162 & 18.2 & $109(43)$ & $12.2(4.8)$ & $1(1)$ & $0.1(0.1)$ \\
\hline & 우 & 787 & 197 & 25.0 & $78(39)$ & $9.9(5.0)$ & - & - \\
\hline Total & - & 1,678 & 359 & 21.4 & $187(82)$ & $11.1(4.9)$ & $1(1)$ & $0.06(0.06)$ \\
\hline
\end{tabular}

表 3 斑 状 歯所有 者

\begin{tabular}{|c|c|c|c|c|c|c|c|c|}
\hline \multirow{2}{*}{ 学年 } & \multirow{2}{*}{ 性 } & \multirow{2}{*}{ 人 数 } & \multicolumn{2}{|c|}{$\mathrm{M}_{0}$ 以上所有者 } & \multicolumn{2}{|c|}{$M_{1}$ 以上所有者 } & \multicolumn{2}{|c|}{$\mathrm{M}_{2}$ 以上所有者 } \\
\hline & & & 実数 & $\%$ & 実数 & $\%$ & 実数 & $\%$ \\
\hline \multirow{2}{*}{1} & $\uparrow$ & 196 & 52 & 26.5 & $19(14) *$ & $9.6(7.1)$ & - & - \\
\hline & 우 & 161 & 55 & 34.1 & $19(14)$ & $11.8(8.7)$ & - & - \\
\hline \multirow{2}{*}{2} & $\hat{\sigma}$ & 171 & 73 & 42.6 & $31(22)$ & $18.1(12.9)$ & - & - \\
\hline & 우 & 138 & 55 & 39.8 & $25(15)$ & $18.1(10.9)$ & - & - \\
\hline \multirow{2}{*}{3} & $\uparrow$ & 159 & 108 & 67.9 & $49(30)$ & $30.8(18.9)$ & - & - \\
\hline & 우 & 152 & 104 & 68.4 & $46(29)$ & $30.2(19.1)$ & - & - \\
\hline \multirow{2}{*}{4} & 令 & 144 & 115 & 79.8 & $68(44)$ & $44.2(29.9)$ & $1(1)$ & $0.7(0.7)$ \\
\hline & 우 & 117 & 94 & 80.3 & $41(32)$ & $35.0(27.3)$ & - & - \\
\hline \multirow{2}{*}{5} & $\hat{0}$ & 108 & 71 & 65.7 & $33(21)$ & $30.5(19.4)$ & - & - \\
\hline & 오 & 112 & 60 & 53.5 & $23(14)$ & $20.5(12.5)$ & - & - \\
\hline \multirow{2}{*}{6} & $\hat{o}$ & 113 & 83 & 73.4 & $42(21)$ & $37.1(18.6)$ & - & - \\
\hline & 우 & 107 & 72 & 67.4 & $34(26)$ & $31.7(24.3)$ & - & - \\
\hline \multirow{2}{*}{ 計 } & $\hat{\delta}$ & 891 & 502 & 56.3 & $242(152)$ & $27.2(17.1)$ & $1(1)$ & $0.1(0.1)$ \\
\hline & 우 & 787 & 440 & 55.9 & $188(130)$ & $23.9(16.5)$ & - & - \\
\hline Total & 一 & 1,678 & 942 & 56.1 & $430(282)$ & $25.6(16.8)$ & $1(1)$ & $0.06(0.06)$ \\
\hline
\end{tabular}

*（）内はいわゆる enamel opaque. 
状歯所有者は増えて， $\mathrm{M}_{0} 21.4 \%, \mathrm{M}_{1} 11.1 \%$, このうち enamel opacities $4.9 \%$ であつた。さら にWHO 式では $\mathrm{M}_{2}$ と判定されるものが 1 名でて くる。

表 3 は，とにかく斑状歯と思われる歯を1本で も有しているものを示した。表にみるように， $\mathrm{M}_{0}$ 以上の歯牙を所有するものは平均 $56.1 \%, \mathrm{M}_{1}$ 以上 $25.6 \%$ (このうち enamel opacities $16.8 \%$ ) と高い比率を示した。とくに 4 年生では実に $80 \%$ が何本かの斑状歯様状態を呈する歯牙を有してい ることになる。

表 1，2，3 で低学年が低い所有者率を示してい るのは萠出歯数が少ないこと, あるいは萠出不完 全であるためため，歯頸部の変化が判定し難いこ となどに原因する。

表 4 はこれら児童の朝起床後 はじめの尿を採尿 し，その尿中フッ素濃度をみたものである。表の ように非常に変動巾が大きく, 平均尿中フッ素濃 度は男 $0.47 \pm 0.31 \mathrm{ppm}$ ，女 $0.44 \pm 0.28 \mathrm{ppm}$ である が，高学年に向つてやや高いフッ素濃度を示寸傾 向があつた。また最高值は $2.50 \mathrm{ppm}$, 最低值は $0.10 \mathrm{ppm}$ であつたが，最低值は学年および男女 間でバラッキが比較的少なく，0.10〜0.12ppmに ほぼ一定していた。

しかしながらこれら尿中フッ素濃度と斑状歯 出現の間に関係を見出すことはできなかつた。

尿糖, 尿 $\mathrm{pH}$ についても，尿中フッ素濃度およ び玟状歯出現との間に関係を認めなかつた。尿蛋 白は+ $(30 \mathrm{mg} / 100 \mathrm{ml}$ 尿) 以上を示すものは認め
表 4 尿中フッ素濃度

\begin{tabular}{|c|c|c|c|c|c|c|}
\hline 学年 & 性 & 人数 & $\overline{\mathbf{x}} \pm$ & $\sigma *$ & 最 高 值 & 最低 值 \\
\hline \multirow{2}{*}{1} & 今 & 196 & 0.42 & 0.23 & 1.30 & 0.11 \\
\hline & 우 & 161 & 0.38 & 0.26 & 2.17 & 0.10 \\
\hline \multirow{2}{*}{2} & 今 & 171 & 0.41 & 0.25 & 1.45 & 0.11 \\
\hline & 우 & 131 & 0.37 & 0.21 & 1.35 & 0.12 \\
\hline \multirow{2}{*}{3} & $\hat{\sigma}$ & 159 & 0.45 & 0.28 & 1.50 & 0.10 \\
\hline & 우 & 152 & 0.46 & 0.30 & 1.74 & 0.10 \\
\hline \multirow{2}{*}{4} & 今 & 144 & 0.45 & 0.29 & 2.20 & 0.11 \\
\hline & 우 & 117 & 0.42 & 0.20 & 1.10 & 0.14 \\
\hline \multirow{2}{*}{5} & 全 & 108 & 0.55 & 0.37 & 1.50 & 0.12 \\
\hline & 우 & 112 & 0.53 & 0.34 & 2.10 & 0.10 \\
\hline \multirow{2}{*}{6} & $\hat{0}$ & 113 & 0.65 & 0.45 & 2.50 & 0.15 \\
\hline & 우 & 107 & 0.51 & 0.31 & 1.30 & 0.10 \\
\hline \multirow{2}{*}{ Total } & - & 891 & 0.47 & 0.31 & \multirow{2}{*}{$(1.68 \pm 0.43)$} & \multirow{2}{*}{$(0.11 \pm 0.016)$} \\
\hline & & 787 & 0.44 & 0.28 & & \\
\hline
\end{tabular}

なかつたが，士（痕跡）を示したものの中には， フッ素濃度の高いものが多くみられる傾向があつ た。表 5 は蛋白が士を示したもののフッ素濃度と 蛋白がーを示したもののフッ素濃度について，そ れぞれ平均值と標準偏差を示したものである。表 のように, 蛋白士群と蛋白一群との間には, フッ素 濃度に関して， 3 年および 5 年生を除き有意な差 を認め， 1 年から 6 年生全体としても， $\mathrm{p}<0.001$ で有意な差を認めた。

表 5 尿中蛋白とフッ素浱度の関係

\begin{tabular}{|c|c|c|c|}
\hline \multirow{2}{*}{ 学年 } & \multicolumn{2}{|c|}{ フ ッ素 湌 度 (ppm) } & \multirow{2}{*}{ A, B 差有意性 } \\
\hline & A. 蛋白 $\pm^{*}$ & B. 蛋白一 & \\
\hline 1 & $0.56 \pm 0.22 \quad(\mathrm{n}=34)^{* *}$ & $0.38 \pm 0.26 \quad(\mathrm{n}=183)$ & $\mathrm{p}<0.001$ \\
\hline 2 & $0.48 \pm 0.24 \quad(n=36)$ & $0.35 \pm 0.20 \quad(\mathrm{n}=155)$ & $\mathrm{p}<0.001$ \\
\hline 3 & $0.58 \pm 0.32 \quad(n=27)$ & $0.54 \pm 0.30 \quad(n=178)$ & $\mathrm{p}<0.5$ \\
\hline 4 & $0.69 \pm 0.32 \quad(n=34)$ & $0.48 \pm 0.31 \quad(n=150)$ & $\mathrm{p}<0.001$ \\
\hline 5 & $0.77 \pm 0.34 \quad(n=13)$ & $0.67 \pm 0.41 \quad(n=147)$ & $\mathrm{p}<0.4$ \\
\hline 6 & $1.32 \pm 0.51 \quad(n=17)$ & $0.67 \pm 0.40 \quad(n=166)$ & $\mathrm{p} \ll 0.001$ \\
\hline Total & $0.67 \pm 0.40 \quad(n=161)$ & $0.51 \pm 0.34 \quad(n=979)$ & $\mathrm{p}<0.001$ \\
\hline
\end{tabular}

* Combistix (Ames 社)：士は痕跡，一は蛋白を認めず。

** 平均值士標準偏差 (ppm), $\mathrm{n}$ は人数。 


\section{考察}

フッ素によつて起こつたと考えられる，いわゆ る斑状歯の判定は，とくにそれが $\mathrm{M}_{0}, \mathrm{M}_{1}$ 程度の 軽度のものである場合には，かなりの経験と熟練 が必要であるといわれている。その上，それがフ ッ素性のものか, 非フッ素性のものかの判断がむ ずかしい。フッ素性斑状歯と判定する一応の基準 として，次のような事柄があげられている ${ }^{4)}$ 。

1. ある程度以上の量のフッ素を，歯牙発育期 中に，ある期間以上摂取していたこと。

2. 地域的あるいは集団的, 家族的にあらわ れ，非フッ素地帯より明らかに高率にあらわれる こと。

3. 同一歯列に, ほぼ左右対称的かつ数歯以上 にあらわれること。(ただし homologous の歯で あつても，その発育に時間差があれば，左右対称
性はなくなる)。

4. 白濁は水平の縞をつくりやすく，また境界 が比較的不鮮明なことが多い。 などである。

今回の藤沢市の場合には，歯牙発育期中のフッ 素の摂取はとくに高いとは考えられず，また地域 的, 集団的に斑状歯の発生のみられるといわれ る，、わゆる高フッ素地帯あるいは斑状歯地帯で もない。しかし，調査結果にも示したように，口腔 診査による判定の段階では，斑状歯あるいは斑状 歯の疑いと判定できるものが比較的多く認められ た。すなわち，一歯列に左右対称的に数歯以上に 存在するものの最高度の 2 歯という著者らの判定 方法に従つても， $4.5 \%$ を $\mathrm{M}_{1}$ と判定とすること ができ，また WHO の判定にしたがつた場合は とにかく一歯列の最高度の 2 歯で判定という考え 方であるから， $\mathrm{M}_{1}$ で11.1\%と高い割合を示した。

個↔の歯牙の判定基準：

表 6 斑 状歯の判定基準

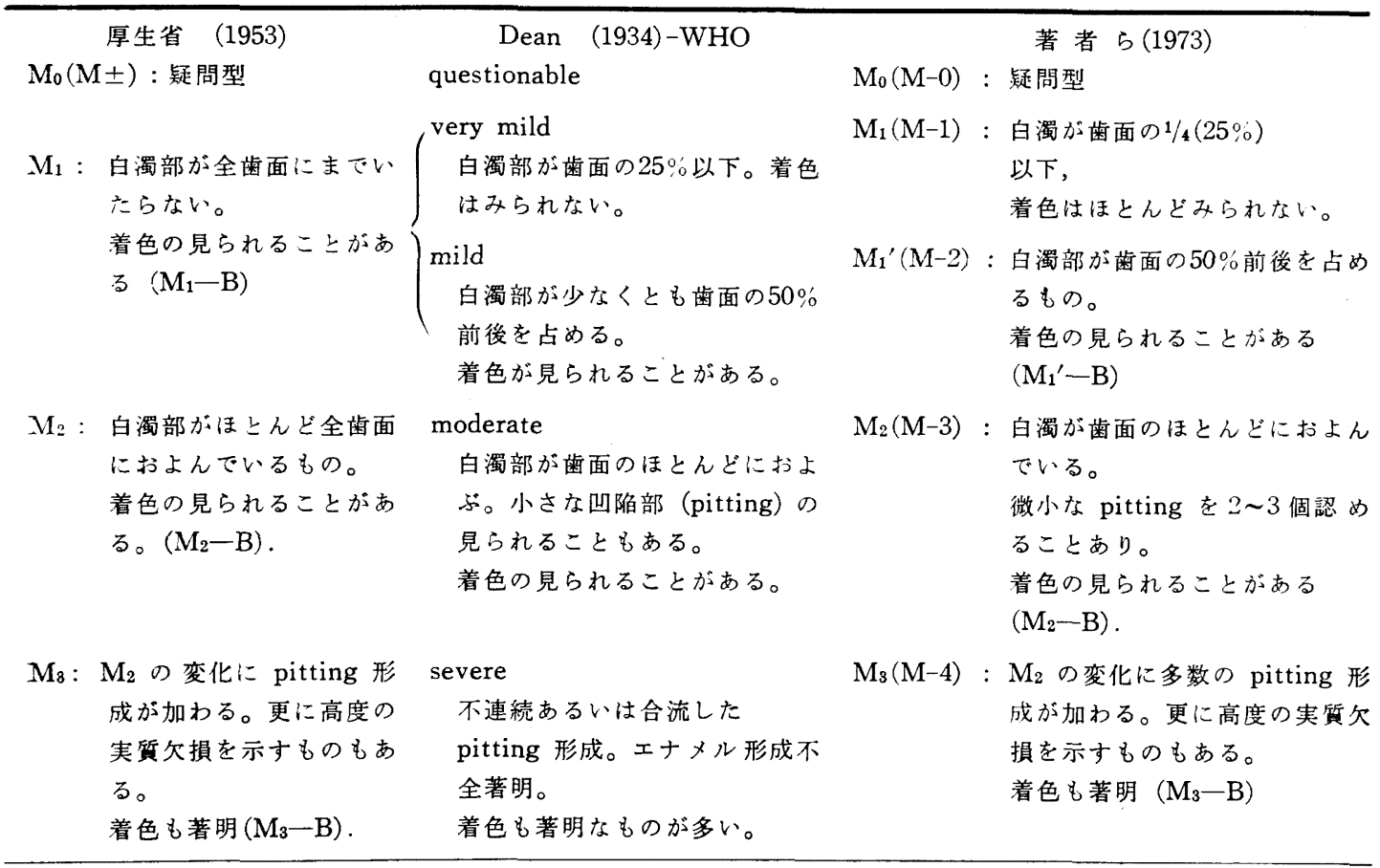

斑状歯におかされている個人の程度の判定基準 :

OWHO の方法—1 歯列に存在する斑状歯の最高度の 2 歯をもつて判定。

○著者らの方法一1 歯列に左右対称に数歯以上（少なくとも 4 歯以上）存在する斑状歯の最高度の 2 歯を もつて判定。 
だから，WHO 式で判定する場合には，それがフ ッ素性のものか Idiopathic なものかといらことは 常にう蝕罹患状態なども含めた他地域の資料と の比較に掞いて判断されなければならないもので ある。さらに，、わゆる斑状歯様の歯面を呈する 歯牙を有する者（ $\mathrm{M}_{1}$ 以上）とすると，実に $25 \%$ 以上の人が含まれ，斑状歯の診査のむずかしさを 感じさせる。

参考のために, 斑状歯の判定基準を, 厚生省, WHO，著者らの方法とで比較したものを表 6 に 示しておく。

非フッ素性斑状歯（いわゆる Idiopathic mottling など）の発現率，成因などに関するデータ は不足しており，成因については歯牙形成期中の ある時期にフッ素をとくに多量に含む飲食物を一 時的に大量に摂取した場合とか，歯牙形成期中に うけた栄養障害，先行乳歯の障害による影響，そ の他 Ameloblasten への直接あるいは間接的影響 によるものと考えられるが，フッ素の多い飲食物 の一時的多量摂取や栄養障害ならば，対称性に数 歯以上に出現するはずである。またもし，栄養障 害によるものであれば，栄養状態の悪さなど地域 的，家族的に現われる可能性もあつて，フッ素性 のものとの判別がまたむずかしいことになる。こ のように, Idiopathic mottling の地域性について など，その成因の解明につながる今後の研究が待 たれる所である。また一方，フッ素地帯では，明 らかな Idiopathic mottling は非常に少ないとも

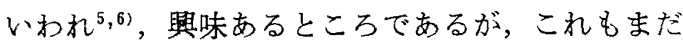
確証が得られているという程ではない。ただ低つ ッ素地区でも 年間平均最高気温が $27^{\circ} \mathrm{C}$ 以下の地 域に Idiopathic mottling の出現率が高いという 所見もある ${ }^{7}$ 。

このように考えてくると，現段階では，それが idiopathic なものであろうといら判定基準はもち ろん非常にあいまいなものではあるが，一応次の ように考えることもできょう。

1. 歯牙形成期中の一定期間, ある程度以上の フッ素の摂取がなかつたと考えられること。

2. 出現してもそのほんどが $\mathrm{M}_{2}$ 以下（多くは $\mathrm{M}_{0}, \mathrm{M}_{1}$ 程度) の斑状歯である。
3. 大部分が非対称性で，かつ一歯列の少数歯 に出現する。

4. 一歯列に数歯以上あらわれることがあつて も，左右対称的ではないことが多い。

5. 白濁部の不透明度が強く，かつその境界が 比較的明瞭なものがある (enamel opacities)。

しかし，フッ素の摂取が明らかな場合であつて も，つまりフッ素地区で斑状歯を判定する場合で も,このような Idiopathic mottling の存在を常 に考慮しなければならないのも当然である。

次に，フッ素性斑状菌を有する者の別な判定法 の一つとして，フッ素の摄取による尿中へのフッ 素の排泄，あるいはエナメル表層中フッ素量の増 大などが考えられている。今回の尿中フッ素濃度 に関する調査ではこれと斑状歯出現の間に関係を 見出すことは出来なかつたが，尿中 F 濃度につい てみれば高学年で比較的高いフッ素濃度を示す傾 向が認められた。これは, おそらく体力, 体位の ちがい，つまり全体的な代謝の量のちがいによる もの，および骨の代謝活性が徐々に低下すること によるものと考えられる。小学生の平均的, 朝起 床後のフッ 素濃度は $0.4 \sim 0.5 \mathrm{ppm}$ と考えられる が,バラツキは大きい。とくに最高值は学年間でか なりのバラッキを示している(1.68士0.43ppm)。 しかし，これに対し最低値は割合一定した值を示 している，これは特別なフッ素摂取のない，いわ ば basic なフッ素の最低排泄濃度がこの位（約 0.1ppm) であると考えることができる。そこで, 尿中のフッ素濃度を用いてFの污染を判断する場 合，とくにF摂取量のあまり多くない場合には, 最高值を目安とするよりは最低値を目安とする方 が正しい判断が可能であるかもしれない。つまり 今まで感覚的に行なわれているように，尿中 F 濃 度の各群比較においては，たんに平均値の比較を 行なうだけでなく，とくに最低值附近の変動（い わば尿中 Fの右方移動）を問題にす心゙きものなの かもしれない。

さらに，結果に示したように，尿蛋白と尿中フ ッ素の関係で興味ある所見が得られた。軽度の蛋 白尿は，正常人であつても運動や精神的艺奮であ らわれることがあり，蛋白尿のみを考えれば，当 
然安静時の尿蛋白あるいは尿沈渣，その他の所見 と共に比較検討されなければならない。しかし注 目すべきことは軽度の蛋白尿であつても，それと フッ素濃度とが正の相関をもつてあらわれたこと である。これは，おそらく腎機能との関係におい て解釈されるものであろうが，フッ素の代謝に関 しては非常に興味ある所見である。このことはま た尿中のフッ素濃度の変動しやすさを示すもので あろうが，これらの背景となる代謝問題に関して は，今回のデータだけでは考察がむずかしい。

尿中のフッ素濃度をもつて, 斑状歯の診断の一 助とすることに関しては多数試料で比較をすれ ば，おおよその傾向をつかまえることはできよう が個人の診断はむずかしいようである。また，そ の他の斑状歯判定の一手段としてエナメル質表層 のフッ素量測定が考えられる。しかしこれも個体 差，あるいは年令差によるバラツキがあり，また エナメル質表層のフッ素測定方法にも多少問題が あり，データも不足しているため，まだフィール ドでの実用化の段階には至つていない。

\section{まと め}

歯牙発育期中における多量のフッ素の摂取， あ るいはその他フッ素による污染などのないと考え られる都市の小学生について，斑状歯に関する調 査および尿検查を行ない，次のような所見が得ら れた。

1）一歯列に左右対称に数歯（4歯）以上存在 するものの最高度の 2 歯という基準（著者らの方 法）に従うと、いわゆる斑状歯と診断される者は $\mathrm{M}_{0} 8.2 \%, \mathrm{M}_{1} 4.5 \%$ (このうち enamel opacities $2.0 \%$ ), 計 $12.5 \%$ であつた。

2）一歯列に存在する 最高度の 2 歯といら基準 （WHO の方法）に従えば， $\mathrm{M}_{0} 21.4 \%, \mathrm{M}_{1} 11.1$ \% (このうち enamel opacities $4.9 \%$ ), 計 32.5 \%であつた。
3） とにかく $\mathrm{M}_{0}$ 以上と考えられる歯牙を 1 歯 でも有する者は平均 $56.1 \%, \mathrm{M}_{1}$ 以上で $25.6 \%$ に も達した。

4）朝起床後のはじめの尿について，尿中フッ 素濃度および尿蛋白, 糖, $\mathrm{pH}$ に関し検査し, 次 の所見を認めた。

i. 尿中フッ素濃度は高学年 でや や高くなる傾 向を認め，これは代謝量のちがいおよび骨の代謝 活性のちがいによるものと考えられる。

ii. 尿中フッ 素濃度の最低值附近は変動が少な く，これをもつてフッ素摂取あるいはフッ素の污 染に対する尿中フッ素濃度の診断基準にするのも 良いかもしれない。

iii. 軽度の蛋白尿と尿中フッ素濃度の間に正の 相関がみられた。

iv. 尿中フッ素濃度と非フッ素性と考えられる 斑状歯出現の間には相関はみられなかつた。

\section{文献}

1）飯塚喜一, 矢崎武, 高江州義矩, 上田喜一：斑 状歯の度分類，F-Workshop，於 東京，1973.

2) 厚生省医務局 : 斑状歯調査要領, 口腔衛生会誌, $1: 39,1953$.

3) WHO : Oral health surveys, Basic methods, WHO, Geneva, 1971, p. 40.

4) 飯塚喜一：口腔衛生学, 永末書店, 京都, 第 1 版, 1972, p. 247.

5) Forrest, J. R. : Caries incidence and enamel defects in areas with different levels of fluoride in the drinking water, Brit. dent. J., $100: 195,1956$.

6) Ast, D. B., Smith, D. J., Wachs, B. and Cantwell, K. T.: Newburgh-Kingston caries-fluorine study; XIV. Combined clinical and roentgenographic dental findings after ten years of fluoride experience; J.A.D.A., $52: 314,1956$.

7) Richards, L. F., Westmoreland, W. W., Tashiro, M., Morrison, J. T. : Nonfluoride enamel hypoplasia in varying fluoride-temperature zones, J. A. D. A., $75:$ 1412, 1967. 


\begin{abstract}
Prevalence of Enamel White Flecks (Idiopathic Mottling) and Urinary Fluoride Level in Schoolchildren in a low-fluoride Area. (Fluoride study No. 12) Yoshikazu IIZUKA*, Takeshi YASAKI*, Katsumi OHHASHI*, Masako KUBOTA*,Hajime OKUDERA*, Takeshi KOIKE* and Akie TSUTA*. Clinical examination of enamel white flecks and urinanalysis were carried out on 1678 schoolchidren, aged from 6 to 11 years, who grew up in a city which supplied city water containing low fluoride (less than $0.24 \mathrm{ppm}$ ).
\end{abstract}

Findings were as follows:-

1) Individuals with one or more teeth in "Very mild" or higher grade condition were found to be about $25.6 \%$ of the sample. On the contrary, according to the criterion for dental fluorosis rating as the two teeth showing the most severe grade developed by Dean (1934), "Very mild or mild" was about $11.1 \%$; however, according to the criterion as the two teeth showing the most severe rating among the several teeth (four or more teeth) distributed symmetrically developed by the authors (1973), "Very mild or mild" was about $4.5 \%$ only. Thus, the authors considered that it is important to take into accout the symmetrical distribution of several mottled teeth and to examine children aged about ten or more years for the assessment of dental fluorosis in specific areas.

2) Fluoride concentration, as well as protein, glucose and $\mathrm{pH}$ of urine samples collected immediately after arising in the morning were analysed. A relatively higher level of fluoride concentration was found in the higher school years than in the lower school years.

Fluoride concentration in samples was ranged widely $(2.5-0.10 \mathrm{ppm})$, a little variation, however, was observed at the level of minimum urinary fluoride level fraction (about $0.1 \mathrm{ppm}-$ $0.15 \mathrm{ppm}$ ). Thus, the increasing of minimum urinary fluoride level of residents would be recommended for the assessment of pollution by fluoride. Besides, a positive correlation between slight (or questionable) albuminuria and urinary fluoride concentration was observed. 